\title{
JOURNAL.RU
}

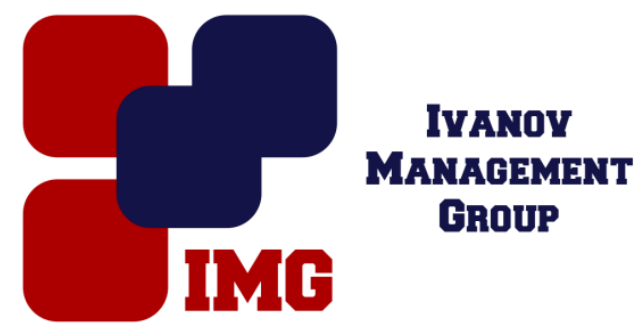

Цулукидзе А.Ю. Академия ФСИН России Рязань, Россия

doi: $10.18411 / 1 \mathrm{j}-31-05-2017-55$

idsp 000001:1j-31-05-2017-55

\section{Этнические проблемы суррогатного материнства}

Желание иметь своего, родного малыша - это так естественно! Для любой женщины - даже той, которая, согласно вердикту врачей, не может иметь детей. Но если раньше диагноз «бесплодие» был приговором для супружеской пары, мечтающей о наследнике, то сегодня надежда есть практически в каждой семье. Все благодаря развитию новых вспомогательных репродуктивных технологий. В том числе и суррогатного материнства, отношение к которому в обществе часто очень противоречивое: от полного принятия и одобрения до резкого отрицания. Что же это - зло или благо? Попробуем разобраться.

История суррогатного материнства уходит корнями в глубокое прошлое. Первая известная нам программа так называемого традиционного суррогатного материнства была реализована почти 4000 лет назад. Эта история описана в Ветхом Завете: Сара, жена Авраама, была бесплодна и наняла свою служанку Агарь, чтобы она выносила ребенка Аврама. «И сказала Сара: вот, Господь заключил чрево мое, чтобы мне не рождать; войди же к служанке моей: может быть, я буду иметь детей от нее». Авраам послушался Сару, и так у них появился мальчик Исмаил - Сара приняла его на свои колени как родного сына.

Подобные случаи описывает не только Библия, но и древнеегипетские папирусы, и эпос Древней Индии. С давних времен проблему бесплодия решали с помощью суррогатного материнства, используя как «сурмам» рабынь и наложниц (такая практика существовала у многих народов, несмотря на культурные и религиозные различия). В общем, судя по всему, суррогатное материнство - практически «ровесник» человечества. 
Почему же тогда вокруг этого явления сегодня идут жаркие споры между медиками, религиозными деятелями и «простыми смертными»? Если медицинский аспект этой репродуктивной технологии абсолютно решен (это можно сделать технологически, и это делается), то юридические, моральные и этические аспекты суррогатного материнства еще провоцируют споры и скандалы. Общество разделилось на два противоположных лагеря - существуют как ярые противники, так и те, кто активно поддерживает суррогатное материнство. Противники суррогатного материнства однозначно заявляют, что: суррогатное материнство - это неестественный процесс, и поскольку он не предусмотрен самой природой, он абсолютно недопустимым в человеческом обществе; суррогатное материнство превращает детей в товар, а товар, как известно, продается и имеет свою цену, это довольно дорогая процедура и поэтому только для богатых, а люди, у которых недостаточно средств и которые имеют те же проблемы, не могут воспользоваться нею и т.п. Против суррогатного материнства выступает и православная церковь, сравнивая эту процедуру с грехом и считая ее противоречащей Библии.

Это, в первую очередь, проблема «лишних эмбрионов» и возможность их уничтожения, продажи, злоупотребления, а также ряд других, которые уже являются предметом дискуссии в течение нескольких десятилетий и, надо сказать, они не решены. В последнее время неожиданно встал вопрос инцеста, который может быть спровоцирован ЭКО. Благодаря ЭКО у одного мужчиныдонора могут быть сотни детей. Теоретически, число потенциальных детей у одного донора может превысить все население земли. На практике действительно, у одного отца оказываются сотни детей, причем юридически они его потомством не являются. Мало того, эти дети - братья и сестры - не знают о своем взаимном родстве. Если в начале распространения ЭКО их были единицы, то теперь тысячи Вероятность встречи и брака далеко не равна нулю, а во втором поколении становится еще более вероятной. При этом никто не несет никакой ответственности за возможные последствия, а они могут быть очень серьезными

Сторонники суррогатного материнства, в свою очередь, отвечают, что современный человек уже давно использует многие вещи, не предусмотренные природой. Самый яркий пример - имплантация больному человеку органов, взятых у других людей. В случае имплантации ни у кого не возникает вопросов о допустимости или недопустимости такой операции и о морально - этической проблеме, возникающей при этом. Это считается правильным и благородным 
делом. Почему же тогда применение суррогатного материнства вызывает столько дискуссий и вопросов? Чем, по сути, отличается суррогатное материнство от имплантации органов с точки зрения морально-этических норм?

Суррогатное материнство поколебало общепризнанный принцип: мать ребенка - та женщина, которая его родила.

В юридической литературе сложилось три точки зрения на эту проблему. Первая не подвергает сомнению приведенное общее правило. Вторая исходит из того, что ребенку передаются генетические особенности организма, из чьего "материала" он "сделан". Соответственно, мать - женщина, давшая яйцеклетку. Третья точка зрения предлагает компромисс: и биологическая, и генетическая матери имеют юридические права на признание материнства, т.е. за ребенком признается наличие двух матерей. Российский законодатель встал на сторону женщины, выносившей и родившей ребенка (как бы перефразировав русскую поговорку:"Не та мать, что зачала, а та, что родила").

Однако многие авторы полагают, что норма о передаче ребенка заказчикам только с согласия суррогатной матери несправедлива.

При всем сочувствии к женщине-заказчице и ее благородному желанию быть матерью, выбранный ею способ материнства все-таки настораживает. Для нее другой человек становится средством, действительно ничем иным, как оплачиваемым инкубатором. Она пренебрегает всеми теми реальными физическими и психологическими проблемами материнства, которые возникают у нуждающейся женщины, готовой за деньги даже родить ребенка. Она разлучает ребенка с родившей его женщиной, т.е. фактически с матерью, могущей его кормить. Она не хочет общения ребенка с родившей его женщиной. Кроме того, нельзя игнорировать и тот факт, что при ВРТ фактически подсаживают не один, а несколько эмбрионов - два или более. А на определенных стадиях развития лишних, как правило, удаляют. То есть, если мы говорили об абортах как об убийстве нерожденных детей, тут осуществляется еще более изощренное убийство - братьев и сестер ожидаемого ребенка, которые уже начали развиваться вместе с ним в лоне суррогатной матери.

На сегодня ни супруги, ни суррогатная мать не чувствуют себя защищенными со стороны государства.

Перевод процедуры суррогатного материнства из непредвиденного к отлаженному процессу позволит избежать многих проблем и, возможно, основной - низкой рождаемости. Несмотря на наличие сторонников или 
противников суррогатного материнства, оно существует, и не только существует, но набирает обороты, как в мире, так и в нашей стране.

Еще один главный этический вопрос: скрывать или не скрывать? Ни одно государство не требует от родителей, использовавших суррогатное материнство, рассказывать об этом своим детям. Это будет рассматриваться как вмешательство в личную жизнь и нарушение автономии семьи. Проблема, с которой сталкиваются родители, состоит в том, что они должны решить, лгать своему ребенку или нет. Дети обязательно задают вопросы вроде «откуда я появился?» Как ответить на них, если было использовано суррогатное материнство? Как правило, биологические родители не афишируют тот факт, что их ребёнка вынашивала суррогатная мать, но есть и исключения.

1. Авхадеев И.В. Некоторые вопросы правового регулирования института суррогатного материнства // Право и образование. М., 2007, № 9. С. 151-158

2. Азарова Е.Г. Социальное обеспечение детей: теоретические подходы: Монография. М.: КОНТРАКТ, 2012. - $256 \mathrm{c}$.

3. Айвар Л.К. Правовые основы вспомогательных репродуктивных технологий (суррогатное материнство) // Юридический консультант. 2006. № - С. 6.

4. Александров А.Ф. Соотношение норм семейного и гражданского права при правовом регулировании применения искусственных методов репродукции человека // Правовое регулирование деятельности хозяйствующего субъекта. Самара, 2004. Ч. 3. - С. 8 - 12.

5. Алексеев Н. А. Гей-брак: семейный статус однополых пар в международном, национальном и местном праве./ Н.А. Алексеев. - М.: БЕК, 2002. - 416 с. 